\title{
The Historicity of the Neronian Persecution: A Response to Brent Shaw
}

\author{
CHRISTOPHER P. JONES \\ Department of Classics, Harvard University, Cambridge, MA 02138, USA. \\ Email: cjones@fas.harvard.edu
}

\begin{abstract}
Brent Shaw has recently argued that the Neronian persecution never occurred. In fact, there are no grounds for doubting Tacitus' report of the persecution. Sources later than Tacitus (Melito, Dionysius of Alexandria) date the martyrdoms of Peter and Paul to the reign of Nero, but those reports have no bearing on the veracity of Tacitus' account.
\end{abstract}

Keywords: Nazoreans, Nero, persecution, Peter, Paul, Tacitus

\section{The Persecution and the Martyrdoms of Peter and Paul}

In an article entitled 'The Myth of the Neronian Persecution', Brent Shaw has called the whole notion of the persecution into question;

A conventional certainty is that the first state-driven persecution of Christians happened in the reign of Nero and that it involved the deaths of Peter and Paul, and the mass execution of Christians in the aftermath of the great Fire of July $64 \mathrm{CE}$... The purpose of historical research is to create by description and explanation [but] sometimes destruction is required ... The simple argument of this essay, deliberately framed as a provocative hypothesis, is that this event never happened and that there are compelling reasons to doubt that it should have any place either in the history of Christian martyrdom or in the history of the early Church. ${ }^{1}$

What Shaw treats as a single 'event' is in fact his own conflation of two events: (1) Nero's punishment of Christians for allegedly setting the Fire of Rome, for which 'the only source is a brief passage in the historian Tacitus', ${ }^{2}$ and (2) the execution of Peter and Paul in this same context. But it is a distortion to tie Tacitus'

1 B. D. Shaw, 'The Myth of the Neronian Persecution', JRS 105 (2015) 73-100, at 73-4 (emphasis added).

2 Whether this was the 'first' imperial persecution depends on whether there was a previous one under Tiberius: cf. T. D. Barnes, 'Legislation against the Christians', JRS 58 (1968) 32-50, 
account of the punishment of Christians to the tradition that Peter and Paul were martyred on the same occasion, and to treat them as one 'event', 'a conventional certainty' requiring 'destruction'. In the following I shall mainly concentrate on the historian's account, though also considering some other relevant texts, both Christian and non-Christian.

It is usually thought that the fire of the year 64 led to a persecution of the Christians by Nero; the chief evidence is a famous passage of Tacitus' Annals (15.44.2-5). After Tacitus, Christian sources mention Nero as the first emperor to persecute Christians. Melito of Sardis says: 'Alone of all people, persuaded by certain malicious men, Nero and Domitian chose to make our Word a

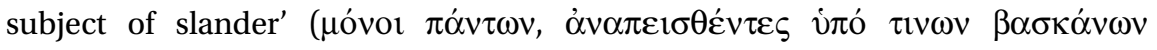

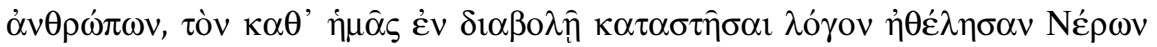

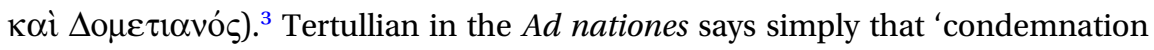
(of Christians) became established under the emperor Nero' (principe ... Nerone damnatio inualuit), ${ }^{4}$ while in the Apologeticum, perhaps drawing on Tacitus, he says: 'Consult your histories. There you will find that Nero was the first to rage with Caesar's sword against this sect, arising at Rome just at that time' (consulite commentarios vestros: illic reperietis primum Neronem in hanc sectam cum maxime Romae orientem Caesariano gladio ferocisse). ${ }^{5}$

Christian traditions first found in the second century imply that Peter and Paul were martyred in Rome, and so possibly in this same persecution. The Letter of Clement to the Corinthians, also known as 1 Clement, talks of both Peter and Paul having died as martyrs, apparently at Rome; ${ }^{6}$ the date of the letter is disputed, and the first part of the second century is possible. In the later second century, Dionysius of Corinth says that both Peter and Paul, 'after having

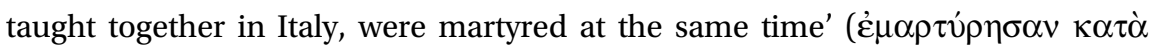

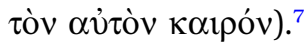

It is thus understandable that modern historians have usually treated the persecution itself as a historical fact, but have doubted whether it also involved the deaths of the two apostles. According to W. H. C. Frend, 'Whether Peter and Paul were among the victims is unknown. ${ }^{8}$ M. Griffin, writing in a standard dictionary, says: 'Without firm evidence of the date and circumstances of Paul's

at 32-3. Suetonius refers to Claudius' expulsion of Jews impulsore Chresto assidue tumultuantis (Claud. 25.4), but even if this refers to Christians, it is not usually counted as a 'persecution'. 3 Melito in Eus. Hist. eccl. 4.26.9, ed. G. Bardy, Sources Chrétiennes 31 (Paris: Éditions du Cerf, 1952) 210.

4 Ad nat. 1.7.8, ed. J. G. Ph. Borleffs, CCSL 1 (Turnhout: Brepols, 1954) 18.

5 Apol. 5.3, ed. E. Dekkers, CCSL 1 (Turnhout: Brepols 1954) 95.

61 Clem. 5.4-7, ed. A. Jaubert, SC 167 (Paris: Éditions du Cerf 1952) 109.

7 Eus. Hist. eccl. 2.25.8, p. 93 Bardy.

8 W. H. C. Frend, The Rise of Christianity (London: Dartman, Longman and Todd, 1984) 109. 
martyrdom, it is difficult to relate his two year-imprisonment in Rome ... to the Neronian persecution of $64 .{ }^{9}$ A recent article on Paul, also in a standard handbook, suggests that Paul's death occurred 'perhaps before the persecution of Christians in the city of Rome by Nero in 64 CE' ('vielleicht noch vor der Verfolgung stadtrömischen Christen durch Nero 64 nC.'). The author adds: 'That Paul suffered martyrdom at the same time as Peter does not emerge from this notice, but is supposed by Dionysius of Corinth about 170 CE' ('Dass $\mathrm{P}$ [aulus] zur gleichen Zeit wie Petrus das Martyrium erlitten habe, geht aus dieser Notiz nicht hervor, wird aber von Dionysius v. Korinth um 170 nC. behauptet'). ${ }^{10}$

\section{Tacitus and the Chrestiani}

According to Tacitus, Nero was widely suspected of having started the fire, and 'to do away with the rumor [he] introduced as alleged defendants and subjected to the most elaborate penalties those hated because of their criminal acts, whom the people called Chrestiani' (abolendo rumori Nero subdidit reos et quaesitissimis poenis adfecit, quos per flagitia inuisos uulgus Chrestianos appellabat, Ann. 15.44.2). The verb subdo implies that these rei were falsely accused; even if technically 'defendants', they were probably not given much chance to offer a defence. ${ }^{11}$ In the only manuscript, the second Medicean, Chrestiani appears to have been changed to Christiani by a later hand: the fourth-century Codex

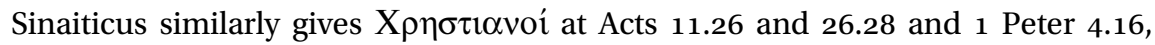
the only appearances of the word in the New Testament, though most witnesses

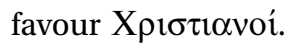

Shaw's main argument against Tacitus' account is his use of Chrestiani for followers of Jesus of Nazareth, 'a manifest anachronism'. The essential passage for the invention of the term is Acts 11.26, concerning the preaching of Paul and Barnabas in Antioch at a date that in Luke's chronology corresponds to the early forties. ${ }^{12}$ So successful was their preaching that they made many converts, 'and the disciples were first called Christianoi in Antioch' $(\chi \rho \eta \mu \alpha \tau i \sigma \alpha l \tau \varepsilon$

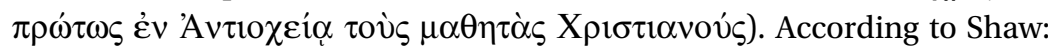

Writing, perhaps, as late as the 9os, it is difficult to control the precise mise-enscène. Even if the students of Jesus began to call themselves Christianoi at some point in the 40s and 50s in an eastern city of the Empire, it is difficult to know

9 Anchor Bible Dictionary Iv (1992) 1080.

10 H. Löhr, 'Paulus I', RAC 26 (2015) 1174.

$11 O L D^{2}$ s.v. subdo $6 \mathrm{~b}$, with several examples from Tacitus; Shaw's translation of subdidit reos, 'found and provided the defendants' ('Myth', 81), misses the implication.

12 Here and throughout I shall use 'Luke' as shorthand for the author of the Gospel of Luke and of Acts, with no assumption about whether the two authors are the same person. 
what sort of general purchase this naming had in the high social and political ranks with which we are concerned. And even if the contemporaneity of the reference could be guaranteed, which it cannot, the use of the term appears to be highly localized and internal to the community itself. ${ }^{13}$

Luke is talking about more than a term 'internal to the community itself': the word $\chi \rho \eta \mu \alpha \tau i \sigma \alpha l$ should rather mean 'were called' (by others), a sense $\chi \rho \eta \mu \alpha \tau i \zeta \omega$ often has in inscriptions and papyri: in that sense it corresponds closely to

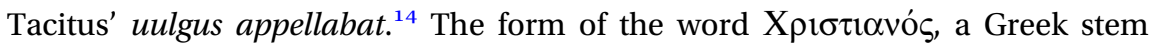
with a Latin suffix, might also buttress Luke's assertion. Among the several meanings of the suffix -ianus is that of a follower of a particular leader, often in a hostile context. An example close in time and space is provided by the senatus consultum de Gnaeo Pisone. Here it is alleged that Piso won over the Syrian legions by paying them donatives from the imperial purse, 'after doing which he was pleased that some of the soldiers were called Pisoniani, others Caesariani' (quo facto milites alios Pisonianios, alios Caesarianos dici laetatus sit). ${ }^{15}$ Syrian Antioch was not just 'an eastern city of the Empire', but one of its largest cities; it was also a polyglot community with a large presence of Roman soldiers; being responsible for maintaining order, these might come into frequent contact with followers of Jesus. Such a place could readily give rise to a linguistic hybrid like

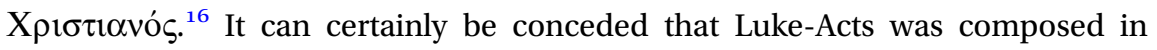
the later first century, whether or not by someone who was a companion of Paul in his later voyages. But the 'difficulty' of characterising and dating the author is not a reason to suppose him ill-informed about the circumstances of early Christianity: other arguments have to be adduced if his testimony is to be impugned.

Shaw indeed advances another argument, drawn from the text of Acts itself. He

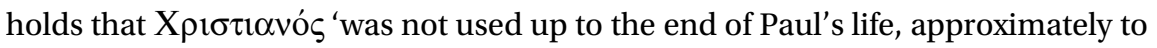
the mid-6o's', since the lawyer Tertullus, when representing the high-priest Ananias before Felix the governor of Judaea, calls Paul 'the ringleader of the

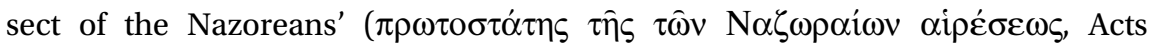
24.5). But this does not show that 'Nazorean' was the only possible word to designate Christians, and that 'Christian' had not yet come into existence. In a

13 Shaw, 'Myth', 88.

14 On $\chi \rho \eta \mu \alpha \tau i \zeta \omega$, see M. J. Wilkins, Anchor Bible Dictionary I (1992) 925: 'The infinitive should be rendered "were called," indicating that the name was coined by those outside of the church.' Cf. also C. P. Jones, 'Epigraphica', ZPE 139 (2002) 110-11.

15 L'Année Épigraphique 1996, 885.55-6. On this passage, see W. Eck, A. Caballos, and F. Fernández, Das Senatus consultum de Gnaeo Pisone patre (Vestigia 48; Munich: Beck, 1996) 175-7.

16 Cf. the suffix -ite in English: originally a Greek termination, serving among other functions to denote a particular person's follower, it has become a productive suffix in words such as 'Luddite', 'Buchmanite'. Cf. the $O E D^{2}$ s.v. -ite. 
passage of direct speech, Tertullus uses 'Nazoreans' for what the Jewish authorities regarded as a deviation (hairesis) within their own religion; it has rightly been observed that they 'were not likely to have referred to the disciples [of Jesus] as Christians, followers of Christos, since this would have validated Jesus' claim to that title'. ${ }^{17}$ As he is represented by Luke, Paul does not repudiate the designation Nazōraios, and the four evangelists use it, or the related Nazarēnos, of Jesus himself. ${ }^{18}$ Eusebius in his gloss on 'Nazareth' treats Nazarēnos simply as a name once used to designate Christians: 'Nazareth: from which Christ was called Nazōraios, and Nazarēnoi, as we who are now Christians (were called) long ago.' ${ }^{19}$ The Jewish use of a related term for Christians persisted after the time of Paul. According to Tertullian, 'Christ, (son of) the Creator, had the right to be called "Nazaraeus" according to the prophecy, and hence the Jews call us by the same name, "Nazarenes", because of him (nos Iudaei Nazarenos appellant per eum)'. The Babylonian Talmud and other texts, including geniza versions of the Birkat ha-Minim ('Benediction concerning heretics'), use nozerim to refer to Christians. ${ }^{20}$

Another passage of Acts, if taken as literally as Shaw takes the speech of Tertullus, shows that Xpıбııvós was already an understood term for Christians in 'high social and political ranks'. This is the difficult passage in which Paul, this time on trial before Festus with Herodes Agrippa also present, says to Agrippa: 'Do you believe the prophets, King Agrippa? I know that you do believe.' Agrippa answers (in one possible translation): 'In a short time you

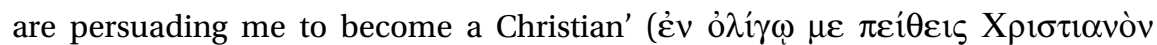
$\gamma \varepsilon v \varepsilon \dot{\varepsilon} \sigma \theta \alpha$, with variant $\pi$ oin $\sigma \alpha \mathrm{l}$, Acts 26.27-8). Both text and interpretation of this passage are disputed, ${ }^{21}$ but Luke evidently intends 'Christian' to denote a follower of Jesus of Nazareth. Shaw, who mentions this passage only in a footnote,

17 M. J. Wilkins, Anchor Bible Dictionary I (1992) 926. Cf. S. Goranson, Anchor Bible Dictionary IV (1992) 1049-50: 'To define Nazarene, one must take into account the time, place, language, and religious perspective of the speaker, as well as the meanings of other available religious group names.'

18 The earliest witnesses unanimously favour N $\alpha \zeta \omega \rho \alpha i 0 \varsigma$ in Matt 2.23; 26.71; John 18.7; 19.19; Acts $2.22 ; 3.6 ; 4.10 ; 6.14 ; 22.8 ; 26.9$, but are divided between $\mathrm{N} \alpha \zeta \alpha \rho \bar{\eta} v o \varsigma$ and $N \alpha \zeta \omega \rho \alpha \hat{i} \mathrm{~s}$ in Mark 10.47; Luke 18.37; 24.19; and John 18.5; Nestle-Aland print N $\alpha \zeta \omega \alpha i ̂ \varsigma$ everywhere except for N $\alpha \zeta \alpha \rho \hat{\eta} v o \varsigma$ in Mark 10.47 and Luke 24.19.

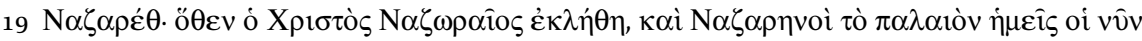

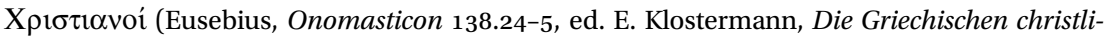
chen Schriftsteller der ersten Jahrhunderte xi.1 (Leipzig: J. C. Hinrichs 1904).

20 Tert. Marc. 4.8.1, ed. A. Kroymann, CCSL 1 (Turnhout: Brepols 1954) 556; ed. C. Moreschini and R. Braun, SC 456 (Paris: Les Éditions du Cerf 2001) 104-5; Shaw, 'Myth', 87 n. 68. Nozerim: R. Langer, Cursing the Christians? A History of the Birkat HaMinim (New York: Oxford University Press, 2012) 57-61, 187-95 and Index s.v.

21 Discussion in F. W. Danker, ed., A Greek-English Dictionary of the New Testament (Chicago: University of Chicago Press, $\left.2000^{3}\right) 791$. 
calls Herod's remark a 'bit of banter, ... a later fiction of some type'. ${ }^{22}$ It is odd method to lean so heavily on the use of 'Nazorean' in the speech of Tertullus and to dismiss as 'a later fiction' another sentence of direct speech in Acts, also spoken in the context of a trial.

\section{The Christian Community in Neronian Rome}

Besides Tacitus' use of Chrestianus, a further argument for supposing him in error, according to Shaw, is that there was not a sufficiently large Christian community for them to have a name. 'Christians, who were probably not called or even known by this name at the time, were hardly a sufficiently distinctive group within the Jewish communities at Rome in the 6os to be noted for their own peculiar identity, much less a well-known group under this name and recognized as such by the ordinary inhabitants of the city. ${ }^{23}$ This is to discount a letter of Paul that is usually considered 'the standard against which the authenticity of other epistles attributed to Paul is measured', ${ }^{24}$ the Epistle to the Romans. After

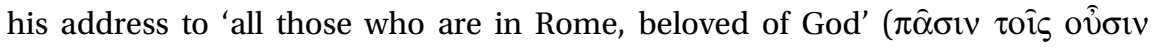

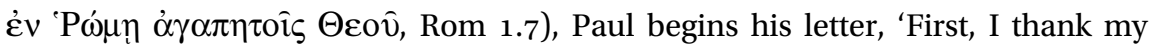
God through Jesus Christ about all of you that your faith is announced in the

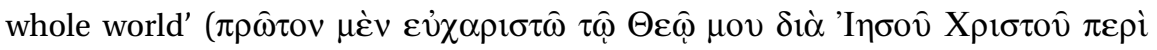

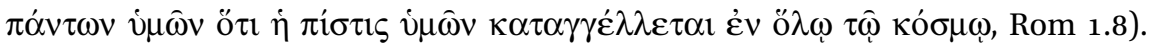
Even if Paul does not use the word 'Christian', this letter is hardly reconcilable with the view that followers of Jesus of Nazareth were not a 'distinctive group' in Rome of the sixties.

If there were not enough Christians in Neronian Rome to be a 'distinctive group', and the term Christianus (Chrestianus) had not yet come into common use by this time, a last question must be: how was Tacitus misled into identifying Nero's victims as Chrestiani? Without impugning his quality as a historian, Shaw argues that when writing the Histories, and especially in his account of the Jews and their religion, Tacitus makes no mention of the Christians, and says that Judaea had been quiet in the reign of Tiberius (sub Tiberio quies, Hist. 5.9.2). Hence 'a different kind of information had come to the historian's attention in the years after he wrote the Histories ... The specific connection of Christians with the fire in Rome as the persons who were punished for the conflagration somehow developed later. ${ }^{25}$ It was therefore through personal and written

22 Shaw, 'Myth', 88 n. 71.

23 Shaw, 'Myth', 89.

24 C. D. Myers, Jr, Anchor Bible Dictionary v (1992) 816. Unless I mistake, Shaw does not mention this text.

25 Shaw, 'Myth', 92, 94. 
interchanges at this social level that Tacitus came to learn of the Christians, and was misled into identifying them with Nero's victims.

As a channel through which Tacitus might have acquired such knowledge, Shaw points to his friendship with Pliny, whose encounter with the Christians of Pontus must have preceded the writing of the Annals. 'The knowledge fields that these men shared about any given social group like "the Christians" can, I think, be assumed to be modestly similar. And yet the one thing that we know about Pliny's knowledge of Christians is that when, as governor of BithyniaPontus, he interrogated some of the accused he knew rather little about them. ${ }^{26}$ But Pliny does not say that he knew 'rather little'. What he says is that he has never been present at hearings on the subject of Christians (cognitionibus de Christianis interfui numquam, Ep. 10.96.1), and hence he is not sure how such hearings are conducted. Sherwin-White is surely right to observe, 'This implies that Pliny knew that such trials had taken place within the period of his public career, and hence at Rome. ${ }^{27}$ If Pliny regarded trials of 'Christians' as routine within the period of his public life, and uses the term with no sign that it is a neologism or a recent introduction, it is likely to have been in use among Latin speakers at least since the eighties. It is also possible, though not provable, that Tacitus had occasion to talk of the Christians in later books of the Histories, especially when describing the reign of Domitian. ${ }^{28}$

\section{Conclusion}

Shaw fails to disprove the usual view that a group already identifiable as followers of Jesus existed in Rome as early as the sixties, and that its members

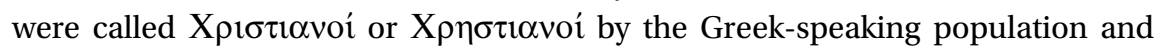
Chrestiani or Christiani by Latin speakers. Equally, he fails to disprove Tacitus' statement that, after the Great Fire, Nero 'introduced as alleged defendants and subjected to the most elaborate penalties those hated because of their criminal acts, whom the people called Chrestiani'. These can be regarded as 'facts'. Whether it is a fact that Peter and Paul died in the Neronian persecution, or is merely a tradition based on slender evidence, is irrelevant to Tacitus or to the historicity of the persecution. ${ }^{29}$

26 Shaw, 'Myth', 90.

27 A. N. Sherwin-White, The Letters of Pliny: A Historical and social Commentary (Oxford: Clarendon, 1966) 694.

28 Tacitus could have mentioned trials of Christians without describing a 'persecution': against the notion of a 'Domitianic persecution', Shaw, 'Myth', 97 n. 113, with bibliography.

29 I am grateful for the comments of Prof. G. W. Bowersock and of the readers for NTS. 